\title{
ПРОБЛЕМА ОСОБИСТІСНО-ПРОФЕСІЙНОГО СТАНОВЛЕННЯ МАЙБУТНЬОГО ЛІКАРЯ ТА ШЛЯХИ ЇЇ ВИРІШЕННЯ У ПРАКТИЦІ ВИЩОЇ МЕДИЧНОЇ ШКОЛИ
}

УДК: 159.923 .2

\section{Лазуренко Олена Олексївна}

Кандидат психологічних наук, старший викладач кафедри загальної $і$ медичної психології Національного медичного університету імені О.О. Богомольия, м. Київ (Україна)

\begin{abstract}
Анотація. Стаття присвячена проблемі особистісно-професійного становлення майбутнього лікаря в процесі професійної підготовки. Зроблено припущення, щуо становлення майбутнього фахівия залежить від навчально-пізнавальної діяльності, яка охоплює не лише оволодіння системою знань, набуття вмінь та навичок, а й постійне самовдосконалення. Представлено аналіз етапів професійного становлення фахівців. Розкрита система професійних компетентностей лікаря. Проаналізовані психолого-педагогічні особливості професійного становлення майбутнього лікаря. Досліджено проблему формування особистості студента 3 точки зору підготовки майбутнього фахівия, розглянуті можливості практичної підготовки студентів-медиків до професійної діяльності. Закономірності професійного становлення майбутніх лікарів досліджено в умовах навчальної діяльності у вищому медичному навчальному закладі. Виділено кілька етапів особистісно-професійного становлення майбутнього лікаря у період професійної підготовки. Визначено особливості формування професійної компетентності майбутніх медиків на етапі професійного становлення. Зроблено висновки та визначені перспективи подальшого дослідження.
\end{abstract}

Ключові слова: професійне становлення, професійна компетентність, професіоналізм, професійна підготовка, особистість лікаря, вища медична школа.

Постановка проблеми. Особистісно орієнтований підхід та гуманізація освіти вимагають необхідність пошуку шляхів удосконалення професійної підготовки фахівців, створення умов для формування їх професійних компетенцій та становлення професійної ідентичності. Через це головною метою укра- їнської системи освіти є створення умов для розвитку і самореалізації кожної особистості, формування покоління, здатного навчатися впродовж життя. Цієї мети можна досягти при умові організації навчально-виховного процесу з урахуванням сучасних досягнень науки, зокрема психолого-педагогічної теорії, підго- 
товкою висококваліфікованих фахівців, здатних до професійного зростання.

Соціальна ситуація в суспільстві вимагає високого рівня професіоналізму та компетентності медичних кадрів, що, в свою чергу, можливо лише за умови докорінної зміни існуючої системи вищої освіти, формування нових ціннісних пріоритетів у професійній підготовці спеціалістів. Ми переконані, що новий вектор навчання у вищому медичному навчальному закладі повинен бути спрямований не лише на оволодіння фаховими знаннями, вміннями та навичками, а й формування особистості, становлення іiї як професіонала, що володіє широким спектром необхідних фахових, особистісних, комунікативних та соціальних компетенцій.

Аналіз останніх досліджень і публікацій. Проблема професійного становлення фахівця сьогодні є актуальною і викликає певне зацікавлення з боку науковців, про що свідчать праці таких відомих вчених, як Л. Асмолов, А Тарновська та ін. Сучасна вітчизняна психологія має в своєму арсеналі значну кількість праць, присвячених різним аспектам особистісного розвитку студентів у взаємозв'язку з їх професіоналізацією. В контексті специфіки студентського віку як важливої стадії розвитку особистості та визначення ролі i місця індивідуально-особистісних рис у формуванні професійно важливих якостей, займались Б. Ананьєв, Г. Балл, А. Бодальов, Г. Данченко, О. Касаткіна, Б. Ломов, С. Максименко,
В. Рибалко та інші. Слід зазначити, що питаннями визначення професіоналізму займались багато вчених (М. Холодная, Ю. Орлов, Е. Климов, Е. Рогов та ін.), кожний $з$ яких відзначав окремі фактори, що безпосередньо впливають на процес розвитку даного феноменy.

Питання дослідження професійного становлення знаходяться у постійному центрі уваги багатьох вчених, які визначають сутність та етапи професійного становлення (С. Зеєр, Е. Климов, А. Маркова та ін.), психологічні особливості (А. Маркова, Л. Мітіна та ін.), психолого-педагогічні умови та чинники професійного розвитку особистості (Л. Мітіна, Л. Виготський, О. Леонтьєв, С.Рубінштейн, Л. Орбан, Л. Рибалко, О. Кокун). У той же час цілий ряд аспектів проблеми залишається недостатньо вивченими i, 3 точки зору нашого дослідження, доцільно розглядати даний феномен стосовно професійної діяльності лікаря.

Виділення невирішених раніше частин загальної проблеми, яким присвячується стаття. Аналіз наукових джерел свідчить про те, що проблема дослідження особливостей професійного становлення майбутнього лікаря залишається недостатньо дослідженою. Однак, на нашу думку, необхідно з'ясувати, яким чином вирішується дана проблема в практиці вищої медичної освіти. Актуальність проблематики, неповнота і суперечливість існуючих даних обумовили необхідність проведення даного дослідження і зумовили вибір теми. 
Мета статті: представити аналіз проблеми особистісно-професійного становлення майбутнього лікаря в процесі професійної підготовки та шляхи іiі вирішення у практиці вищої медичної школи. Ми вважаємо за доцільне вивчити проблему формування особистості студента з точки зору підготовки майбутнього фахівця, а також проаналізувати і узагальнити існуючі у сучасній психології теоретичні підходи до проблеми професійного розвитку особистості; розглянути особливості професійного становлення на різних етапах професіоналізації особистості; намітити основні шляхи активізації процесів особистіснопрофесійного розвитку майбутніх лікарів.

Виклад основного матеріалу дослідження. Професіоналізація є цілісним процесом, однією з стадій якого є освоєння професії медичного фахівця, відтак значна частина роботи з особистісного та професійного становлення лікаря здійснюється під час навчання у медичному навчальному закладі, де відбувається перетворення особистості молодої людини в професіонала медичної справи. Здійснений у попередніх наших дослідженнях аналіз проблеми підготовки медичних кадрів показав, що це складна, багатоаспектна галузь психології праці, яка ще недостатньо вивчена i потрібує наукового обгрунтування нових соціально-психологічних явищ саме у сфері професійної освіти.

Професійне становлення як системне утворення починає формуватися на ранніх стадіях професіоналізації і розвивається протягом усього свідомого життя людини, що підкреслюється у провідних концепціях сучасних дослідників (В. Бодров, Е. Зеєр, В. Орел, А. Реан та ін.). Аналіз сучасних труднощів у підвищенні якості професійної підготовки медиків визначив напрямок і проблему дослідження. Складність вивчення цієї проблеми обумовлена наявністю великого числа різнопланових соціально-психологічних факторів, що впливають на становлення особистості лікаря і визначають ефективність професійної медичної діяльності.

Професійне становлення особистості це цілісний динамічний процес від формування професійного самовизначення до повної реалізації себе у діяльності, що передбачає формування професійно важливих якостей. Через це, переконані, професійне становлення особистості має як освітній, так і особистісний рівні зростання.

Професія медичного працівника - особлива за своєю сутністю, значущістю і суперечливістю. Вона передбачає специфічні психічні і емоційні навантаження. 3 огляду на це, доцільно припустити, що за час навчання у вищому медичному закладі студенти повинні не тільки набути необхідні знання з фахових медичних дисциплін, а й розвити відповідні психологічні якості, сформувати позитивне ставлення до майбутньої професії, від чого в повній мірі буде залежати успішність їхньої практичної діяльності. Подальше становлення 
майбутнього фахівця залежить від навчальнопізнавальної діяльності, яка охоплює не лише оволодіння системою знань, набуття вмінь та навичок, а й постійне самовдосконалення.

Сьогодні є достатньо підстав розглядати професійне становлення лікаря як процес, що включає, з одного боку, формування сукупності знань, умінь і навичок та, з іншого професійно значущих особистісних психологічних якостей. Першою з названих складових традиційно приділяється значна увага, підтвердженням чого останнім часом стала реалізація в країні концепції безперервної медичної освіти, проте проблема методології психологічного супроводу особистості лікаря на всіх етапах його професійного розвитку, на жаль, розроблена недостатньо.

Професійна діяльність лікаря проходить в умовах підвищених соціопсихологічних вимог і пов'язана 3 високим розумовим $\mathrm{i}$ психоемоційним напруженням. Активність лікаря в умовах професійного стресу, особливості емоційного реагування на різні ситуації професійної діяльності, фактори, що впливають на професійно-особистісний розвиток суб'єкта лікувального процесу, індивідуальнопсихологічні особливості, властиві лікарям різних спеціалізацій - це ті проблеми, що недостатньо вивчені. Можна сказати, що питання психології праці та особистості лікаря стоять в ряду найважливіших і маловивчених проблем теоретичної та прикладної психології в цілому і окремих її галузей, зокрема.
Враховуючи специфіку професійної діяльності лікаря, важливим фактором ії ефективності є професійна компетентність. 3 огляду на це, доцільно припустити, що основним завданням навчання і виховання, результатом професійного становлення фахівця у вищому медичному навчальному закладі $є$ формування професійної компетентності студентівмедиків.

Відповідно до концепції професійного розвитку особистості, професіоналізм лікаря включає не лише ефективне виконання своєї професійної діяльності, а й зрілість особистості фахівця, поєднання професійно важливих якостей з психологічними у процесі кваліфікованої лікувальної взаємодії.

Висока соціальна значимість медичної праці, пов'язаної з факторами дестабілізуючого впливу на особистість лікаря, з одного боку, і відсутність науково обгрунтованої системи психологічного забезпечення розвитку медика на всіх етапах його професійного і життєвого шляху, з іншого, є тією проблемою, що обумовлює назрілу соціальну потребу визначення психологічної специфіки професійної діяльності лікаря і формування на цій основі концепції послідовного психологічного супроводу становлення особистості професіонала. Іншими словами: очевидна теоретична, методологічна та практична потреба у системному психологічному дослідженні специфіки професійної діяльності лікаря як напрямку сучасної психології праці. 
Період навчання у вищій медичній школі відіграє особливу роль у процесі формування особистості лікаря, саме тому, на наше глибоке переконання, питання особистісного становлення фахівця, зокрема лікаря, 3 точки зору, їх майбутньої професійної діяльності має постійно знаходитись у центрі уваги. 3 цією метою навчально-виховний процес підготовки майбутнього лікаря має передбачати не лише професійний, а й особистісний розвиток фахівця, як на етапі додипломної, так i на етапі післядипломної підготовки.

Професійне становлення особистості лікаря відбувається не лише під час навчання у вищому медичному навчальному закладі. Велику роль відіграють якості особистості, які розвиваються та вдосконалюються у процесі здобуття освіти та у подальшій трудовій діяльності. Професійне становлення майбутнього лікаря є поетапним моментом індивідуальноособистісного розвитку фахівця.

Здійснений у попередніх наших дослідженнях аналіз концепцій та моделей професійно-особистісного розвитку та становлення фахівців на етапі фахової підготовки, дозволив визначити та окреслити кілька етапів професіогенезу особистості лікаря від етапу професійної психологічної готовності та адаптації до етапу професійної майстерності, джерелом якої виступають не лише особисті якості лікаря, а і його професійні компетенції.

Перший важливий етап - це професійне самовизначення майбутнього лікаря, враху- вання його професійних інтересів, нахилів. Він включає вибір професійної освіти і рівень професійної підготовки. Другий етап - це процес професійної підготовки студента-медика, оволодіння професійними знаннями. Третій етап, коли випускник розпочав практичну діяльність, в тому числі професійне навчання в інтернатурі. У нього є можливість застосовувати набуті теоретичні знання, вдосконалити свої вміння та відпрацьовувати навички. Важливими є психологічна готовність до професійної діяльності та усвідомлення професійної ідентичності майбутнім лікарем. Четвертий етап - виконання професійних обов'язків. Це період набуття власного досвіду, самостійного виконання кваліфікованої професійної діяльності, формування професійних компетентностей, власного професіоналізму, проектування кар'єрного зростання. Важливими є подальший професійний саморозвиток та самовдосконалення. П'ятий етап - висококваліфікована діяльність, професійна мобільність, професійна майстерність.

Професійне становлення лікаря, 3 нашої точки зору, передбачає формування професійно важливих знань, вмінь, навичок, індивідуальних властивостей та способів виконання професійних обов'язків у процесі лікувальної взаємодії. В цілому, можна виділити основні складові професійного становлення лікаря. По-перше, спрямованість особистості, що включає мотиви, ціннісні орієнтації, соціально-професійний статус тощо. По-друге, про- 
фесійна компетентність - сукупність професійних знань, вмінь та навичок, способів виконання професійної діяльності. По-третє, професійно важливі якості лікаря.

Провівши грунтовний аналіз сучасних тенденцій розвитку освіти у багатьох країнах світу, переконані, що відбір і впровадження ключових компетентностей стає пріоритетним методологічним та дидактичним завданням, вирішення якого суттєво впливає на розробку державних стандартів освіти, навчальних програм, методичного супроводу процесу навчання, систем оцінювання результатів освіти тощо.

Відмінністю сучасного етапу розвитку вищої медичної освіти є застосування компетентнісного підходу та підвищення вимог до професійної підготовки спеціалістів. Відтак, зміни пріоритетних напрямків в освіті, не можуть стояти осторонь вищої професійної освіти, в тому числі професійної підготовки медичних кадрів. Отже, на вищі навчальні заклади медичного профілю покладена велика відповідальність у професійній підготовці майбутніх фахівців, де акцент робиться на їі якості.

В останні роки в системі професійної освіти все більше уваги приділяється компетентнісному підходу, в якому відображена прийнята в більшості розвинених країн загальна концепція освітнього стандарту, орієнтованого на формування у випускників системи загальнокультурних і професійних компетенцій. Компетентнісний підхід є способом дося- гнення нової якості освіти. Він визначає напрямок зміни освітнього процесу, пріоритети, змістовний ресурс розвитку. Різні аспекти проблеми формування професійних компетенцій глибоко і різнобічно досліджені в теорії професійної освіти, виявлені дидактичні можливості окремих навчальних дисциплін у формуванні компонентів професійної компетентності (Е. Зеер, I. А. Зимня та ін.).

Компетентнісний підхід дозволяє поновому подивитися на професійну підготовку. Через освітні стандарти визначається структура компетенцій, які повинні бути сформовані у випускників освітньо-професійною програмою та освітньо-кваліфікаційною характеристикою, а також новітніми освітніми технологіями. За цим підходом, акцент робиться на результаті освіти, при цьому результатом є не сума засвоєної студентом інформації, а здатність особистості діяти, практично вирішувати професійні завдання, вільно орієнтуватися в складних ситуаціях своєї професії. Саме компетентнісний підхід орієнтований на результат, тобто орієнтує освіту на формування компетентної особистості, сприяє формуванню компетентності випускника.

Компетентність майбутнього лікаря це особистісна та професійна, теоретична i практична підготовка, володіння певним набором професійних компетенцій. Іншими словами, у формуванні компетентності професіонала центральне місце має посідати організована активна, пізнавальна, самостійна діяльність 
кожного студента-медика, який зацікавлений пізнати «секрети професії». У свою чергу, наявність компетентностей дає змогу практично використовувати набуті в процесі навчання знання, застосовувати їх продовж подальшої професійної діяльності, активного життя.

Для сучасної професійної підготовки майбутніх медичних кадрів актуальним є гармонічна єдність особистісного та компетентнісного підходу.

Сучасний фахівець на високому професійному рівні має володіти певними компетентностями. Так, предметна (фахова) компетентність характеризується професійними знаннями та уміннями, здатністю їх реалізовувати. Дослідницька компетентність $є$ важливою для фахівців, які уважно стежать за розвитком подій у своїй галузі і розвивають себе як науковці. Компетентність безперервного навчання включає можливість вчитися та сприяти власному професійному розвитку. Соціальна компетентність передбачає наявність комунікаційних та інтеграційних здібностей, вміння підтримувати відносини, впливати, домагатися свого, правильно сприймати та інтерпретувати думки інших, висловлювати своє ставлення тощо. Комунікативна компетентність розглядається як здатність встановлювати необхідні контакти за допомогою вербальних і невербальних засобів в різних ситуаціях спілкування. Інтелектуальна компетентність виражається в здатності до аналітичного мислення і здійснення комплексного підходу до вико- нання своїх обов'язків. Емоційна компетентність включає особистісні властивості фахівця: чуйність, врівноваженість, рефлексію, емпатію, толерантність тощо. Вона є важливим чинником професійного становлення майбутніх фахівців. Встановлено, що високий рівень саме емоційної компетентності $є$ передумовою успіху в професіях, пов'язаних з інтенсивною взаємодією з іншими людьми.

Таким чином, сьогодні існує об'єктивна потреба у фахівцях нової формації. Відтак, доречними є заходи щодо оновлення освітніх технологій, перебудови професійної вищої медичної освіти, врахування досвіду соціальної практики та великий попит на професію лікаря. Підготовка майбутніх лікарів повинна набути особистісних, компетентнісних пріоритетів та включати, крім навчального процесу, певні заходи, що спрямовані на отримання практичного, професійного досвіду, формування особистості фахівця вже в процесі професійної підготовки у вищому медичному навчальному закладі.

Специфічними чинниками розвитку особистості студента у вищому медичному навчальному закладі $є$ формування професійно значущих компетенцій, а також особистісне становлення майбутнього лікаря. В цілому можна виділити інтегральні характеристики професійної діяльності лікаря і констатувати, що професіоналізм лікаря має визначати співвідношення, з одного боку, його професійних знань, вмінь та навичок, а, з іншого - сформо- 
ваних психологічних особистісних властивостей. Висококваліфікований лікар, який постійно взаємодіє, контактує з іншими, складне і динамічне життя якого накладає високі вимоги до його особистості, має бути освіченою людиною не лише в галузі загальних і спеціальних здібностей, а й бути психологічно обізнаним. Саме тому, на наше глибоке переконання, щоб бути конкурентним у професійному колі, лікар має володіти психологічною компетентністю - тією особистіснопрофесійною якістю, важливою складовою професійної діяльності, яка виражає певний рівень особистісної, соціальної, комунікативної зрілості лікаря.

Вивчення сучасного стану професійної підготовки майбутнього лікаря свідчить, що вирішенню зазначеного завдання у Національному медичному університеті імені О. О. Богомольця, на жаль, приділяється недостатня увага.

Аналіз державного стандарту вищої медичної освіти показав, що провідна роль у формуванні психологічної компетентності майбутнього лікаря належить предметам гуманітарного циклу, серед яких особливе місце посідають психолого-педагогічні дисципліни. Результати аналізу навчальних планів та програм підготовки медичних фахівців показують, що існує об'єктивна суперечність між потребою майбутнього фахівця в оволодінні знань $з$ психології та реальною можливістю отримати їх у процесі навчання у вищому ме- дичному навчальному закладі. Розв“язати цю суперечність, на наше глибоке переконання, можна шляхом формування професійної психологічної компетентності майбутнього лікаря, оскільки вона поєднує, з одного боку, професійну компетентність, а 3 іншого, формування індивідуальних властивостей особистості фахівця.

Розуміючи, що формування психологічної компетентності майбутнього лікаря не $є$ єдиним завданням навчального процесу у ВМНЗ, необхідно забезпечити розвиток індивідуальності фахівця, зокрема формування його професійної психологічної компетентності протягом процесу навчання у вищому медичному навчальному закладі.

Проведений нами аналіз засвідчив недостатню представленість грунтовних досліджень, спрямованих на вивчення розвитку психологічної компетентності студентівмедиків та підкреслив актуальність даного дослідження. Важливість такого кроку підкреслюється тим, що психологічна компетентність як системне, цілісне та динамічне психологічне утворення, як важлива особистіснопрофесійна якість, складова професійної діяльності лікаря, виступає засобом ефективної лікувальної взаємодії і дозволяє прогнозувати успішність фахівця, його професійне становлення.

Особистісний розвиток студента, формування його готовності до майбутньої професійної діяльності є важливими чинниками в 
оптимізації навчального процесу у вищих закладах освіти на сучасному етапі розвитку суспільства. У свою чергу, навчально-виховний процес у вищому медичному навчальному закладі є невід'ємною складовою частиною розвитку особистості студента - майбутнього лікаря, що сприяє формуванню його професіоналізму. 3 огляду на це, доцільно припустити, що основним завданням навчання і виховання, результатом професійного становлення фахівця у вищому медичному навчальному закладі $\epsilon$ розвиток студентів, а відтак, формування їх психологічної компетентності. Важливим є й той факт, що в процесі професійної психологічної підготовки медичних кадрів формування професійної психологічної компетентності майбутніх лікарів $є$ одним 3 провідних завдань, що призводить до сприятливих умов спілкування лікаря з пацієнтом. Крім того, на наше глибоке переконання, починати процес формування психологічної компетентності лікаря необхідно ще в період професійної підготовки у вищому медичному навчальному закладі.

Одним із важливих завдань сучасної вищої медичної освіти виступає створення умов, науково-методичного супроводу, побудова навчального процесу, які б могли бути основою формування професійної психологічної компетентності, сприяти високому рівню розвитку індивідуальності майбутнього лікаря. На наш погляд, розгляд даного питання 3 позиції виявлення потенціалу теоретичної під- готовки майбутнього лікаря полягає у вивченні державного стандарту підготовки фахівця в галузі медицини, а також відповідних навчальних програм. Інший напрямок в дослідженні проблеми формування психологічної компетентності майбутнього лікаря передбачає, на наш погляд, аналіз практичної підготовки, як на додипломному, так і на післядипломному етапі. Аналіз державного стандарту вищої медичної освіти (зокрема освітньо-професійні плани та програми) показав, що навчальні дисципліни, передбачені даним документом, мають певний потенціал формування психологічної компетентності майбутнього фахівцялікаря. Кожний $з$ циклів навчальних дисциплін (гуманітарних, соціально-економічних, фундаментальних, професійно-орієнтованих) має певні можливості для формування психологічної компетентності. Все ж таки, провідна роль у формуванні означеної якості особистості майбутнього лікаря належить предметам гуманітарного циклу, серед яких особливе місце посідають психолого-педагогічні дисципліни. Такі навчальні предмети гуманітарного циклу, як «Основи психології. Основи педагогіки» (для студентів медичних спеціальностей); «Загальна психологія», «Вікова та педагогічна психологія», «Психологія особистості», «Психологія спілкування», «Експериментальна психологія та психодіагностика» та інші (для студентів лікарів-психологів) мають більший потенціал формування психологічної компетентності. У зв'язку з цим, подальше 
вивчення змісту дисциплін даного циклу проводилось нами одночасно $з$ дослідженням відповідних навчальних програм, розроблених у вищих медичних навчальних закладах.

На жаль, у державному стандарті вищої медичної освіти підготовки фахівців за спеціальностями «Лікувальна справа», «Педіатрія», «Медико-профілактична справа», «Стоматологія» опанування психологічними знаннями здійснюється лише на 1 та 3 курсах і в недостатній, як на наш погляд, кількості годин. Аналіз навчальних програм 3 підготовки майбутніх лікарів показав, що в них немає тем, розділів, присвячених психологічній компетентності лікаря. Виключенням є програми, розроблені для студентів спеціальності «Медична психологія»: психологія діяльності медичного працівника, психологічні особливості професійної діяльності, психогігієна професійної діяльності медика, які, на нашу думку, сприяють не лише становленню фахівця, а й формуванню професійних психологічних компетентностей лікаря. Зрозуміло, що аналіз змісту вищої медичної освіти буде не повним без ви вчення можливостей практичної підготовки майбутніх лікарів до професійної діяльності. Мова йде про навчання на післядипломному рівні, в інтернатурі. В першу чергу, про суміжні дисципліни (елементи практичної психології, медична психологія, психологія спілкування та інші) для лікарів-інтернів за різними спеціальностями (акушерство та гінекологія, анестезіологія, дерматологія, епідеміологія, неонатологія, ортопедія та травматологія, офтальмологія, педіатрія, стоматологія, хірургія, медична психологія та інші). На основі проведеного нами аналізу виявляється суттєвий недолік в оволодінні лікарями-інтернами навичок психологічної спостережливості, діагностиці емоційних станів пацієнтів, а також відсутність можливості доповнення теоретичної бази практичними навичками в регуляції та керуванні емоційними станами тощо. Про це, зокрема, свідчать і анкетні дані, запропоновані лікарям-інтернам на першому етапі нашого дослідження, в яких вони зазначають прогалини в даному аспекті професійної підготовки i вказують на бажання оволодіти професійними психологічними навичками.

Тому, враховуючи ці міркування, нами було виділено кілька етапів особистіснопрофесійного становлення майбутнього лікаря у період професійної підготовки у ВМНЗ. Так, на першому етапі (теоретична підготовка) відбувається оволодіння студентами теоретичними i емпіричними знаннями; другий етап (практична підготовка) спрямований на оволодіння студентами-медиками знаннями 3 основ професійної компетентності, застосування набутих знань, формування вмінь і навичок у навчально-пізнавальному процесі; на третьому етапі (інтернатура) відбувається застосування набутих знань, корекція умінь і відпрацювання навичок у процесі практичної діяльності (практикум професійних навичок).

В той час, слід також зазначити, що не- 
можливо змінювати обсяги теоретичної i практичної професійної підготовки фахівця, а формування психологічної компетентності майбутнього лікаря не є єдиним завданням навчального процесу. Саме тому, на наш погляд, необхідно знайти такий підхід, вибудувати таку програму, яка зможе забезпечити розвиток індивідуальності фахівця, зокрема формування його професійної психологічної компетентності протягом всього процесу навчання у вищому медичному навчальному закладі. Найбільш перспективними, на наш погляд, шляхами вирішення поставлених завдань у навчально-виховному процесі вищого медичного навчального закладу мають стати інтеграція навчальних дисциплін соціальногуманітарного циклу, впровадження спеціально розроблених елективних (вибіркових) курсів, проблемних навчально-наукових семінарів, застосування тренінгових занять тощо.

В рамках цього було розроблено спеціальний курс «Психологія діяльності медичного працівника», спрямований на формування зрілої особистості та професійної ідентичності лікаря, психологічної готовності до професійної діяльності, власного професійного стилю; створення умов для усвідомлення фахівцем своїх власних професійних можливостей; профілактику синдрому «професійного вигорання» фахівця; усвідомлення студентамимедиками необхідності турботи про власне фізичне та психологічне здоров'я; розвиток у майбутніх медичних фахівців систематизова- них уявлень, теоретичних знань та практичних вмінь, які дозволять адекватно і ефективно застосовувати отримані знання в подальшій професійній діяльності. У свою чергу це сприятиме розвитку професійної ідентичності, професійних якостей лікаря; становленню образу ефективного професійного майбутнього; актуалізації професійних та особистих ресурсів; формуванню професійної та інших компетентностей фахівця; розвитку професійної рефлексії тощо.

Висновки. Проблема підготовки кваліфікованих кадрів у галузі медицини охоплює широке коло питань. Кінцевим, найвищим результатом професійного становлення лікаря $\epsilon$ його професіоналізм, що виявляється в абсолютній психологічній готовності до ефективного виконання своїх обов'язків. Специфічними чинниками розвитку особистості студента у вищому медичному навчальному закладі $€$ набуття вищої освіти, а також професійне становлення майбутнього лікаря. Важливими завданнями сучасної технології навчання $є$ забезпечення якісної освіти, іiі особистісної орієнтації, створення умов для оновлення змісту і форм організації навчально-виховного процесу, запровадження освітніх інновацій та інформаційних технологій, формування професійної самосвідомості фахівця. 3 огляду на це, підготовка майбутніх лікарів набуває особливого значення. На основі сучасної освітньої доктрини виникає потреба вивчення і наукового обгрунтування якісної професійної підго- 
товки медичних фахівців. Лише високий професіоналізм медичних кадрів може вирішувати складні завдання забезпечення національної безпеки. Через це виникає необхідність підвищувати не тільки якість медичної освіти, але стимулювати особистісний розвиток майбутнього лікаря, що сприятиме формуванню нової компетентної медичної еліти.

Перспективи подальших досліджень. Аналіз проблеми особистісно-професійного становлення майбутнього лікаря та шляхи іiі вирішення у практиці вищої медичної школи показав, що це складна, багатоаспектна галузь психології ще недостатньо вивчена у сфері професійної освіти і потрібує наукового обгрунтування та розробки концепції і подальшого вивчення особливостей професійного становлення лікаря.

\section{Перелік використаних джерел:}

1. Зеєр Е. Ф. Психология профессионального развития: уч. пособие для студ. высш. уч. заведений /Е.Ф. Зеєр. М.: Издательский центр «Академия», 2007.

2. Климов E. A. Индивидуальный стиль деятельности // Психология индивидуальных различий. Тексты / Под ред. Ю.Б. Гиппенрейтер, В.Я. Романова. - М.: Изд-во МГУ, 1982.

3. Кокун О. М. Оптимізація адаптаційних можливостей людини: психофізіологічний аспект забезпечення діяльності: Монографія. - К.: Міленіум, 2004.

4. Лазуренко О. О. Аналіз передумов формування емоційної сфери та проявів емоційного потенціалу особистості студента в процесі професійної підготовки / О.О. Лазуренко // Молодий вчений. - № 5, травень 2014. - С. 127-131.
5. Лазуренко О. О. До питання щодо розвитку поняття «емоційна компетентність» у психології / О.О. Лазуренко // Науковий огляд. - №1 (11). - Київ, 2015. - С. 116123.

6. Лазуренко О. О. Концепція формування емоційної компетентності на різних етапах професійної підготовки лікаря/ О. О. Лазуренко // Науковий вісник Херсонського державного університету. Серія: Психологічні науки. - Випуск 3. - Херсон, 2015. - С. 113-117.

7. Лазуренко О. О. Психологічні особливості формування емоційної компетентності майбутнього лікаря: дис. ... канд. психол. н. : 19.00.07. - Київ, 2017. - 270 с.

8. Лазуренко О. О. Тенденції модернізації професійнопсихологічної підготовки лікарів: компетентнісний підхід / О. О. Лазуренко // Психологічний часопис. - №1 (11) $2018 .-$ C. $87-100$.

9. Лазуренко О. О. Психолого-педагогічні особливості моделювання професійної компетентності студентівмедиків у процесі професійного становлення/ О.О. Лазуренко // Психологічний часопис. - №3 (13) 2018. - С. 67-86.

10. Маркова А. К. Психология профессионализма. - М.: РАГС, 2006.

11. Пряжников Н. С. Профессиональное и личностное самоопределение. - М.: Изд-во «Институт практической психологи»; Воронеж: НПО "МОДЭК". - 1996.

12. Толочек В. А. Современная психология труда. СПб.: Питер, 2005.

13. Тертична Н. А., Лазуренко О. О. Компетентність як ціннісна орієнтація у професійній підготовці медичного психолога / О. О. Лазуренко, Н.А. Тертична // Особистість та їі історія: 3б. матеріалів VII Міжнародної науково-практичної конференції. - Ніжин, 2017. - С. 103105 . 


\section{References (Transliteration):}

1. Zeer E. F. Psihologiya professional'nogo razvitiya: uch. posobie dlya stud. vyssh. uch. zavedenij /E.F. Zeer. - M.: Izdatel'skij centr «Akademiya», 2007.

2. Klimov E. A. Individual'nyj stil' deyatel'nosti // Psihologiya individual'nyh razlichij. Teksty / Pod red. YU.B. Gippenrejter, V.YA. Romanova. - M.: Izd-vo MGU, 1982.

3. Kokun O. M. Optimizaciya adaptacijnih mozhlivostej lyudini: psihofiziologichnij aspekt zabezpechennya diyal'nosti: Monografiya. - K.: Milenium, 2004.

4. Lazurenko $O$. O. Analiz peredumov formuvannya emocijnoï sferi ta proyaviv emocijnogo potencialu osobistosti studenta v procesi profesijnoï pidgotovki / O.O. Lazurenko // Molodij vchenij. - № 5, traven' 2014. - S. 127 -131 .

5. Lazurenko $O$. $O$. Do pitannya shchodo rozvitku ponyattya «emocijna kompetentnist'» u psihologiï / O.O. Lazurenko // Naukovij oglyad. - №1 (11). - Kiïv, 2015. S. 116-123.

6. Lazurenko O. O. Koncepciya formuvannya emocijnoï kompetentnosti na riznih etapah profesijnoï pidgotovki likarya/ O. O. Lazurenko // Naukovij visnik Hersons'kogo derzhavnogo universitetu. Seriya: Psihologichni nauki. Vipusk 3. - Herson, 2015. - S. 113-117.

7. Lazurenko $O$. O. Psihologichni osoblivosti formuvannya emocijnoï kompetentnosti majbutn'ogo likarya: dis. ... kand. psihol. n. : 19.00.07. - Kiïv, 2017. - 270 s.

8. Lazurenko $O$. $O$. Tendenciï modernizaciï profesijnopsihologichnoï pidgotovki likariv: kompetentnisnij pidhid / O.O. Lazurenko // Psihologichnij chasopis. - №1 (11) 2018. - C. 87-100.

9. Lazurenko O. O. Psihologo-pedagogichni osoblivosti modelyuvannya profesijnoï kompetentnosti studentivmedikiv u procesi profesijnogo stanovlennya/ O.O. Lazurenko // Psihologichnij chasopis. - №3 (13) 2018. C. 67-86.

10. Markova A. K. Psihologiya professionalizma. - M.: RAGS, 2006
11. Pryazhnikov N. S. Professional'noe i lichnostnoe samoopredelenie. - M.: Izd-vo «Institut prakticheskoj psihologi»; Voronezh: NPO "MODEHK". - 1996.

12. Tolochek V.A. Sovremennaya psihologiya truda. - SPb.: Piter, 2005.

13. Tertichna N.A., Lazurenko O.O. Kompetentnist' yak cinnisna orientaciya u profesijnij pidgotovci medichnogo psihologa / O. O. Lazurenko, N.A. Tertichna // Osobistist' ta iii istoriya: Zb. materialiv VII Mizhnarodnoï naukovopraktichnoï konferenciï. - Nizhin, 2017. - S. 103-105.

\section{Lazurenko Olena}

PhD (Psychological sciences), Senior Lecturer, Department of General and Medical Psychology, Bogomolets National Medical University, Kyiv (Ukraine)

\section{THE PROBLEM OF PERSONAL AND PROFESSIONAL DEVELOPMENT OF THE FUTURE DOCTOR AND THE WAYS OF ITS SOLUTION IN THE PRACTICE OF HIGHER MEDICAL SCHOOL}

\section{ABSTRACT}

The article is devoted to the problem of professional development of a specialist. One of the tasks of the system of national higher education is the training of highly skilled specialists. The analysis of scientific sources suggests that the problem of studying professional development is in the constant focus of many scholars who determine the nature and stages of professional development, psychological peculiarities, psychological and pedagogical conditions and factors of professional development of the individual. The problem of studying the peculiarities of the professional competence of doctors in the process of professional development and its influence on professional activity remains insufficient- 
ly investigated, and the insufficient level of development of professional competence of graduates of medical universities negatively affects the effectiveness of future professional activities. The formation of professionalism of a future specialist depends on educational and cognitive activity, which encompasses not only mastering of the system of knowledge, acquisition of skills and abilities, but also constant self-improvement. The essence and stages of professional formation are determined. Professional formation of a personality is a holistic dynamic process from the formation of professional self-determination to the full realization of oneself in the activity. Professional formation of the person has two vectors educational and personal growth. Professionalism is an indispensable component of competence in a particular activity. The stages of development of the doctor in the professional sphere, stages of formation of professional abilities in the process of mastering the profession are considered. The general characteristic of professional formation and level of professionalism is given. Competence is defined as the acquired experience as a long process of acquiring the skills and skills necessary to achieve a high level of mastery in a particular area of life, in particular professional. Given the specifics of the professional activities of the doctor, an important factor in its effectiveness is professional competence. The main task of training and education, the result of professional development of a specialist in a higher medical school is the formation of professional compe- tence of medical students. The professional competence of a doctor is a complex of skills acquired in the process of training the knowledge, skills and abilities necessary for the performance of their professional duties. The model of professional formation and formation of professional competence of the future doctor is presented. The analysis of stages of professional formation of specialists is presented, psychological and pedagogical peculiarities of formation of professional competence of future physicians at the stage of professional formation are determined. The stages of professional psychology of the personality of the doctor from the stage of professional psychological readiness and adaptation to the stage of professional skill are outlined. Analyzed psychological and pedagogical peculiarities of the professional formation of the future physician allow us to talk about the possibility of developing professional competence of a specialist. Educational process of preparation of the future doctor should provide not only professional, but also personal development of a specialist, both at the stage of pre-diploma, and at the stage of postgraduate training. The analysis of the concepts and models of professional and personal development and the formation of specialists at the stage of professional training was carried out in our previous studies. It allowed identifying and outlining several phases of the person's professional psychology from the stage of professional psychological readiness and adaptation to the stage of professional mastery, the source of which is not only the personal 
qualities of the doctor, but also his professional competencies.

A detailed analysis of the psychological peculiarities of the professional development of a future physician allowed us to talk about the possibility of developing professional competence of a specialist. Based on this analysis, it can be assumed that the acquisition of knowledge, skills and abilities associated with the professional competence of a doctor will promote the development of professionalism as an integral quality of the personality of a specialist. The concept of professional development of the physician's personality allows us to conclude that the professionalism of the personality of the doctor and his professionalism are realized in professional activity. Each stage of professional development is characterized by a peculiar combination of personality and professional features, which are manifested in the process of professional activity, which, in turn, requires the former professional competence of the doctor. The results of the research on the problem of professional development of the individual, the formation of professional competence of a specialist in a higher medical school dictate the urgent need for continuation and further study of the features of the doctor's professional training.

Key words: professional formation, professional competence, professionalism, professional training, personality of the doctor, higher medical school.

\section{Лазуренко Елена}

Кандидат психологических наук, старший преподаватель кафедры общей и медиџинской психологии Наџионального медицинского университета имени А. А. Богомольиа, г. Киев (Украина)

\section{ПРОБЛЕМА ЛИЧНОСТНО- ПРОФЕССИОНАЛЬНОГО СТАНОВЛЕНИЯ БУДУЩЕГО ВРАЧА И ПУТИ ЕЕ РЕШЕНИЯ В ПРАКТИКЕ ВЫСШЕЙ МЕДИЦИНСКОЙ ШКОЛЫ}

Аннотация. Статья посвящена проблеме личностно-профессионального становления будущего врача в процессе профессиональной подготовки. Одной из задач системы национального высшего образования является подготовка высококвалифицированных специалистов. Анализ научных источников свидетельствует о том, что проблема исследования профессионального становления находится в постоянном центре внимания многих ученых, которые определяют сущность и этапы профессионального становления, психологические особенности, психолого-педагогические условия и факторы профессионального развития личности. Социальная ситуация в обществе требует высокого уровня профессионализма и компетентности медицинских кадров, что, в свою очередь, возможно только при условии коренного изменения существующей системы высшего образования, формирование новых ценностных приоритетов в профессиональной подготовке специалистов. Мы убеждены, что новый вектор обучения в высшем медицинском учебном заведении должен быть направлен не только на овладение профессио- 
нальными знаниями, умениями и навыками, но и формирования личности, становления ее как профессионала, обладающего широким спектром необходимых профессиональных, личностных, коммуникативных и социальных компетенций.

Профессиональное становление личности - это целостный динамичный процесс от формирования профессионального самоопределения до полной реализации себя в деятельности, предусматривает формирование профессионально важных качеств. Поэтому, убеждены, профессиональное становление личности имеет как образовательный, так и личностный уровни роста. Каждый этап профессионального становления характеризуется своеобразным сопоставлением личностных и профессиональных особенностей, проявляющихся в процессе профессиональной деятельности, которая, в свою очередь, требует сложившейся профессиональной компетентности врача.

Отличием современного этапа развития высшего медицинского образования является применение компетентностного подхода и повышения требований к профессиональной подготовке специалистов. Изменения приоритетных направлений в образовании, не могут стоять в стороне высшего профессионального образования, в том числе профессиональной подготовки медицинских кадров. Проведя подробный анализ современных тенденций развития образования во многих странах мира, убеждены, что отбор и внедрение ключевых компетентностей становится приоритетной методологической и дидактической задачей, решение которой существенно влияет на разработку государственных стандартов образования, учебных программ, методического сопровождения процесса обучения, систем оценки результатов образования и т.д. На основе современной образовательной доктрины возникает необходимость изучения и научного обоснования качественной профессиональной подготовки медицинских специалистов. Только высокий профессионализм медицинских кадров может решать сложные задачи обеспечения национальной безопасности. Из-за этого возникает необходимость повышать не только качество медицинского образования, но стимулировать личностное развитие будущего врача, что будет способствовать формированию новой компетентной медицинской элиты. Перспективы дальнейших исследований. Анализ проблемы личностнопрофессионального становления будущего врача и пути ее решения в практике высшей медицинской школы показал, что это сложная, отрасль психологии еще недостаточно изучена в сфере профессионального образования и требует научного обоснования и разработки концепции и дальнейшего изучения особенностей профессионального становления врача.

Ключевые слова: профессиональное становление, профессиональная компетентность, профессионализм, профессиональная 
подготовка, личность врача, высшая медицинская школа.

Дата отримання статті: 14.04 .2018

Дата рекомендації до друку: 18.04.2018

Дата оприлюднення: 19.04.2018 